\title{
Re-Writing Muslim Identity and Self against Western Discourse of Terrorism in
}

\author{
Naqvi's Home Boy \\ * Abdul Rashid, Lecturer \\ ** Dr. Sarwat Jabeen, Assistant Professor (Corresponding Author) \\ *** Sara Shahbaz, Lecturer
}

\begin{abstract}
Since, the incident of 9/11, the identity of the Muslims across the globe have gone through serious misrepresentations by the western media. This paper provides the insights that how the Muslims have been treated as suspected ones by the westerns. The loyalties of the Muslims were suspected and doubted in America in response to the incident of 9/11. Muslims were victimized on account of their negatively perceived identity. In-Home Boy the Muslim immigrants consistently attempt to re-write and negotiate their identity in response to their misrepresentations of identity. For thematic analysis, theoretical insights have been taken from Almond's The New Orientalists: Postmodern Representations of Islam from Foucault to Baudrillard. The textual analysis of the novel reveals that the Muslims in the western world were already suspected due to the orientalist mind-set of the American society but the incident of 9/11 aggravated this situation in practical social settings. Naqvi speaks for the voiceless Muslims of the third world whose identities had been erased by blowing discursive discourse of 9/11. Naqvi provides readers the sufferings of the Muslims and extends the relevance of 9/11 from Euro-American context to the non-western i.e. the Asians.
\end{abstract}

Keywords: Constructed Discourse of Terrorism, Misrepresentation of the Muslims, the Strategy of Counter Discourse, Re-defining Muslim Identity.

\section{Introduction}

The phenomenon of identity consciousness has been a central concern of humans for centuries. The process of identification, formulation, and re-writing has remained consistent with individuals and nations. Lewis (1990) considers that being human means conscious of having a self and the nature of the self is central to what it means to be human. Identity on account of being a relational term highlights the power relations of an individual within the society. Self is taken consciousness of one's own identity while the "other" is taken in the sense of differentiation and parallel binary of the Self (Burk, 2009). Giroux (2009) points out that the new political movement project new challenges and dimensions for the construction of identity. Post colonialism as a movement reinforced the constructs of identity at large. The notions of the "Self" and "Other" got prominence as a postscript of colonialism. Postcolonial states as a product of such movement anticipated national and religious identities across the borders. More recently, the incident of $9 / 11$ as a historical rupture, developed a paradigmatic process of identification, labelling, and power relations particularly between the Muslims and the victims of $9 / 11$ i.e. the Americans. Since the incident of $9 / 11$, the identity of Muslims underwent serious challenges of misrepresentation by the discursively constructed discourse of terrorism against Islam and the Muslims. The misrepresentation of the Muslims by the American beyond the bounds of reality is evidence of the inherent orientalist perspectives of the American society. To be Muslim was projected with negative connotations as a terrorist by the American intelligentsia and media. In response to the construction of the dichotomy of "the West vs. the Terrorists" in the post 9/11 period, a plethora of misrepresentation evolved against Muslims. Muslims in the western discourse has been represented as a nation that loves violence instead of peace. Quran has been misrepresented as a text, which urges its followers to violence. Resultantly, Islam, and Muslims were projected as a potential enemy of the West. It was a monolithic Westernized perspective of reality. In the wake of this westernized canon, it was difficult for

* Department of English, Bahadur Sub Campus Layyah Email: abdulrashid@bzu.edu.pk

** Department of English, Bahauddin Zakariya University Multan Email: Sarwat.awan4@ gmail.com

*** Department of English, The Women University Multan Email: Saras.wum11@gmail.com 
Muslims to resist the upcoming discourse of misrepresentation. The Muslims on account of being powerless and Subalterns had to resort to radical methods of redefining their identity and self in this new deal (Buchowski, 2006) which further deteriorated the social situation. Erikson (1968) suggested that identity is relative among different groups. He delineates that a stronger sense of identity is developed when the weaker group is emancipated from the identity of the powerful group or community. The weaker group finds the answer to the question of their identity as "Who am I?"

Keeping in view the global political contexts, Castells (2011) argued that globalization is based on the dichotomy of imbalance between the powerful and powerless and it has generated the conflicting trends of identity between the powerful and the powerless. Extending this dichotomy of the "powerful vs. powerless" in the context of $9 / 11$, we see that the identity of Muslims as a weaker group underwent serious challenges of misrepresentation. In Eriksonian terms, it was natural for the Muslims to redefine their identity and self against the discourse of misrepresentation.

Almond (2007) identified Islam as a central phenomenon that shaped a deluge in the context of globalization. The western intelligentsia took the incident of $9 / 11$ as an extension of existing orientalist binaries that had divided the world into categories of "Us vs. Them". Even before the incident of 9/11, Islam and Muslims have been represented as a serious threat to the western world. The western world took the incident of $9 / 11$ as a practical manufacture of existing conflicting binaries. Thus the incident of $9 / 11$, proved Islam as "other" of the west. This situation further complicated the existence of Muslims in the West. To mitigate the Western misrepresentation, the Muslims had to redefine their religious ideologies i.e. Jihad and the concept of practicing Muslims' to minimize their social sufferings on account of their misrepresented identity.

The western discourse against terrorism represented "Islam and the West" in an inherently conflict-based dichotomy (Said, 2002). Here it is explicit that first, we should deconstruct the westernized constructed orientalist analogy of "Islam vs. West". Firstly, Islam as a divine religion cannot be an appropriate analogy of geographical entity i.e. the West. Secondly, a terrorist is marked as one who implants a situation of fear and chaos among the masses for obtaining particular political leverages. Terrorism and its derivative "terrorist" provoke negative and disenchanting feelings on account of its malignancy (Almond, 2007). We see that

- Terrorism is a deliberate attempt of exploitation

- $\quad$ Fear and violence are used for political change not as a religious one.

By this definition, we can assert that terrorism has political context and orientation rather than a religious one. The prime objective of a terrorist seems to create a situation of psychosocial chaos for political gains and games. So, Terrorism is essentially concerned with political deterrence only (Hoffman, 2006). It is meant to instill fear among targeted audiences that might be taken as a rival based on ethnicity or an entire country, a national government or political party, or public opinion in general. So, we see that terrorists seek to obtain political leverage, influence, or political power which they may be unable to gain on a local or international scale otherwise.

Woodward (2004) extends that identity is a phenomenon of similarity or difference. We identify the people who are alike us on our side. We feel a sense of association towards these people who are on our side. While sensing the difference we construct a situation of otherness and indifference. So, identity is essentially our social artifact about a society where we live with others. Identity caters to an association between individuals and the world in which they live. Thus the phenomenon of identity encompasses both subjective and the external domains of identification simultaneously. It is an individually and socially documented position of an individual.

Hence, the construction of identity is embedded with individuals and the collective categorization of a person. Haugaard relates that those in powers always maintain and enforce their hegemony on the weak and creates their powerful position in the social and political domains (Haugaard, 2006).

In Haugaard's words, the process of identity formation uses history, collective memory, geographical landscapes, and fantasies of individuals, political and religious exposures as materials of construction. In the situation of social crisis, individuals, social groups, and societies re-arrange all such indicators to recreate their identities (Castells, 2011). Mills (2003) considers discourse as a tool of power that can perform the function of interruption, stumbling resistance, and a starting point as an opposing strategy". It means that if there is no discourse, there will be no "resistance". So, discourse is also considered as a source of the liberating tool as well. In the post 9/11 scenario, western society 
used its previous historical, collective memory and political indicators as means of misrepresenting the Muslim identity, while the Muslims had to take the same elements as a counter-strategy to redefine their identity and self. The present paper is an attempt to measure how the western intelligentsia eulogized the discourse of terrorism against the Muslims and which strategies the Muslims adopted to reconcile against the misrepresentation of their self and identity.

\section{Theoretical Formulations}

Almond (2007) in The New Orientalists: Postmodern Representations of Islam from Foucault to Baudrillard traced that the Muslims in the post 9/11 context have consciously been taken and projected as "Orient and other" of the West. Islam as a religion has been represented as nightmarish for the Western world. Almond presented the chronological evolution of Islam in parallel to the globally western hegemonic order. He also traced the contours which Islam had adopted to re-route the socially constructed resistance against it. He articulated that every individual, society, and ideology had its own Orient (Buchowski, 2006). Similarly, Islam has consciously been taken as the "other" of the western society. Orientalism as a tool of the intelligentsia for the exploitation and misrepresentation of those who do not possess power was introduced by Edward Said in 1978. In Saidian terms, orientalism is a set of discursive practices of discourse by which the West constructed and imagined the East politically as fascist, socially as chaotic, militarily as dreadful, ideologically as terrorist and devoid of scientific reasoning. Further, Orientalism created ontologically and epistemologically the conflicting binary of 'the Orient' and the Occident". Such representation of the orient by the Europeans is a typically intentional one and enables the western as legitimate and powerful to maintain their political and ideological dominance over subjugated orients. So, we see that Islam as a divine religion and Muslims as the followers of Islam have been intentionally taken as the "other" of the western Occidentalism. This analogy even in the pre-9/11 context proves that Islam and the Muslims were facing underlying misrepresentation by western discourse practices. In the post 9/11 context, these discursive practices aggravated the situation of social exclusion as powerful cultural hegemony already in work. As discursive hardening permits politically stronger groups to define weaker groups according to their own will. In post 9/11 discourse the issue of alterity and the epistemological validity of the "other" evolved as a more pressing theme in political discourse as well. The same discourse also got manifestation in post $9 / 11$ fiction. In the post 9/11 period, the western discourse was actively engaged in the following categories of representation.

1. The construction of such modes by which the other is created.

2. The construction of a universal cognitive social model of "Us" vs. "Them."

3. An analytical model which may enable authors to construct narration against Islam and the Muslims.

As we have already identified that the process of identification always remains under construction and cyclic form. Here is the cyclic process by which the identity undergoes the process of misrepresentation and re-construction

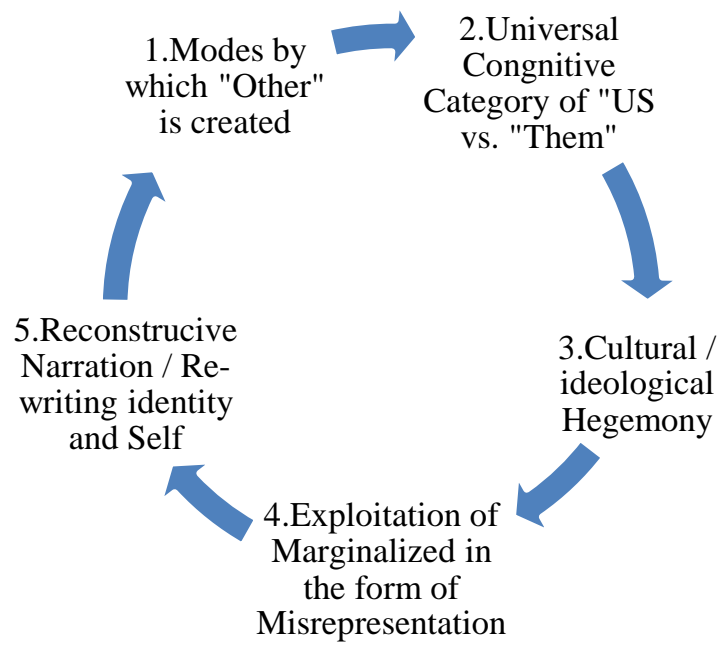

Fig. 1 
Adapted from Almond's The New Orientalists: Postmodern Representations of Islam from Foucault to Baudrillard

As the world has turned into more complex rubrics, the process of identification and its representation has taken become complex. Recently, the process of making "the other" has assumed various forms in social life i.e. ideological, political, economic, and social.

Shifts in collective identities and the meaning of "the other" have become a part of the transformations in Europe. We see that counter-narrative by the orient as a misrepresented category against the discursive narrative is justified and essential mode of the cyclic process. The Muslims are bound by this model of representation to rewrite their self and identity.

\section{Textual Analysis}

The novel Home Boy revolves around the central character of Chuck and his friends Muhammad shah, Ali Chaudhry (AC), and Jameel who are Pakistani immigrants residing in America. At the time of the attack on Twin Towers in New York, they were residing there. With the incident of 9/11, he and his friends had to face the situation of serious social discrimination on account of their negatively perceived Muslim identity.

\section{Pre 9/11 Ambivalent Identity of the Muslims in America}

Naqvi's novel the Home Boy represents the American consciousness which developed against Muslims after the incident of $9 / 11$ as a social artifact. Simultaneously, he represents the counternarrative- a narrative of the Muslims. We see that the Americans discourse was heavily obsessed with hatred against Muslims. In response to the incident of 9/11, the American society contrary to its proclaimed democratic and cultural openness developed a strong Orientalist model of "US vs. Terrorist". This was the wrong turn that America took in the post 9/11 scenario. Chuck narrates that we were turned into the margins of different identities which were unknown to us before $9 / 11$. "We'd become Japs, Jews, Niggers. We weren't before... we had our fingers on the pulse of the great global dialectic" (Naqvi, 2010, p.3)

9/11 in its cultural understanding proved a historical rupture and unprecedented event in the history of America. At the beginning of the novel, Chuck's inclinations towards America were ambivalent. He assimilates himself into the American culture by developing sameness with the American citizens "I'd since claimed the city and the city had claimed me" (Naqvi, 2010, p.3). But he could not detach himself completely from his home country, i.e. Pakistan. "We listened to Nusrat and the new generation of native rockers (Naqvi, 2010, p. 4). Thus 9/11 proved such a socio-political event that prompted chaos and complexities for Pakistani immigrants in America and turned the Muslims' identity as outlaws of the land.

\section{Strategies of Counter Discourse Adopted by the Muslim Characters to Re-write their Self and Identity}

The Muslim characters in the novel Home Boy developed a strong consciousness of their identity. They started re-defining and re-writing their identity as social artifacts in the following ways.

\section{- $\quad$ Reconstruction of Self}

Before the incident of 9/11, American society was prejudiced against Muslims. But such discrimination was tolerable for Chuck, Muhammad Shah, and AC. But the incident of 9/11 shattered their notion of America as a safe place to live in. Chuck was beaten up by a gang of bar brawlers. He and his friend are disparagingly called "A-rabs" (Naqvi, 2010, p.12) with the connotation of barbers.

Castells argues that the resistance identity is generated by those actors who are in powerful positions. Such actors intentionally devalue those who are weak or marginalized. The stigmatized logic of domination and exploitation generates the discourse of resistance based on the survival. Thus resistance and survival become the trait of society in which stigmas prevail (castells, 2011). 9/11 proved as a cultural stigma for the American society in which the identities of Chuck, AC, and Jimbo were judged through the lens of American National consciousness. As a correcting strategy of identity social stigmas are in need to be re-evaluated. In response to these threats, the Muslim characters attempt to reconstruct their identity.

\section{- $\quad$ Redefining Jihad: Holy Warriors vs. Bastards of War}

An important speech is delivered by AC to re-define the Taliban as a political by-product of American trained warriors against Russia. According to AC, they (Taliban) have no concern with Islam. So, they can never be the representative of Islam.AC provides the stigma of American ideology towards the Mujahideen that they were Holy warriors at the time of war against Russia. 
According to AC, the Taliban were "all transmogrified into the villains of modern civilization, but you know, they're not much different from their fathers - brutes with guns - except this time they're on the wrong side of history"(Naqvi,2010,p.13). This constructed Otherness experienced by Chuck was humiliating for him. He mirrors himself as the "Other of Europe" Baudrillard argued that in such conflicting situations the "Other" is compelled to redefine "the rules of the game". The American national discourse erased the identity of the Muslims by projecting them as the terrorist. As a natural will the Muslim characters for example the protagonist of Naqvi's novel reverses the rule of the game. Chuck openly challenges the American stance that how the Taliban can be considered as the representative of the Muslims and Islamic ideology? At one time Taliban were patronized by America. Now they were turned as the representative of Islam and Muslims.

\section{- $\quad$ Reviving Muslim cultural values and Collective Consciousness}

Chuck re-defined his Self by developing a strong sense of collective consciousness of Muslim identity. He recounts that he is not the only Pakistani who is being harassed socially but the frequent negative reports of media revealed to him that a lot of other Muslims around him in New York were being harassed and perceived as traitors. Although he was unable to control the American media from the negative and misrepresentation of the Muslims but he was in anguished condition on the negatively constructed image of the Muslims by the American media. He questions the American hypocrisy; on one hand claiming as a promising state of religious freedom while on the other hand, developing a situation of social scrutinization for the Muslims on the pretext of "Material Witness Statute" Chuck in reaction to his social scrutinization and discrimination inclines to his religious and cultural identity. Initially, when AC's sister Amo used to wear hijab, Chuck despite knowing the hijab as a cultural symbol of religious identity "did not care to wear one's identity on his/ her sleeve" (Naqvi, 2010, p.17). But later on, Chuck becomes adhesive to the cultural symbols of his religion. He strongly favors that the Muslims should practice their identity through cultural symbols as contours of their religious identity and self. The western media took the concept of jihad from the Islamic ideology as an ideological apparatus of killing the innocent people-the Americans. While Old Man Khan- a Muslim character of Naqvi's novel, rectifies the concept of jihad as doing some God's work, making Heaven on Earth. Chuck purports the redefining of the word jihad in its original sense is a revision strategy.

\section{- $\quad$ Redefining Muslim Identity versus Western Discourse of Terrorism}

The incident of 9/11 projected Islam as an ideology that promotes terror and violence. In other words, it seems that the American war against terror was directly against Islam and the Muslims. We have to keep in mind that any religion can never be violent while any ideology can dwindle on both sides. Taking Islam as a parallel to the American capitalist ideology, the Americans developed a direct association between Muslims and terrorism.

Grizzly: You are a terrorist?

Chuck: No, sir.

Grizzly: You a Moslem?

Chuck: Yes, sir.

Grizzly: So you read the Ko-Ran? (Sick) (Naqvi, 2010, p.98)

Chuck re-defines and defends the Muslim stance against terrorism that the one how reads the holy Quran should not be supposed to be a terrorist. Similarly, it never means that the one who reads the Quran would strictly follow the religion as an ideology and would be violent. Even a Muslim cannot pray five times a day and can drink wine contrary to his religious teachings but still can be a good Muslim. Naqvi conversed with the Western World that a Muslim with strong or weak belief should not be supposed as a terrorist. If the one who reads the Quran is considered a terrorist, why can a Christian who reads the Bible not be charged as a terrorist?

\section{- $\quad$ Redefining Quranic ideology against stereotypes of Terrorism}

The western intellectuals misunderstood that the Quran as a book which propagates the discourse of violence and terrorism. Grizzly in conversation to Chuck speaks the predominant and impending American misconception towards Quran the sacred book of Muslims. The gauge which the American had laid for the definition of a terrorist is that any Muslim, who recites the Quran, offers prayers five times a day, is a potential terrorist.

"Grizzly: I want to know does the Koran (sick) sanction terrorism. 
Chuck: I've read it. I'm no terrorist

Grizzly: Then why do Moslems use it to justify terrorism?" (Naqvi, 2010, p.103)

While Chuck as a re-defining strategy of his self and religious identity, justifies that it is the matter of interpretation. He elucidates that unfortunately, the western world has misinterpreted the Quran and its teachings. Chuck says that it is all a matter of interpretation... I mean take the Bible. It's interpreted differently by, like, Unitarians and Mormons, Lutherans, Pentecostals.

During the conversation, Chuck as a representative of Islam and Muslims redefines that he has read the Quran and it does not sanction any sort of terrorism. It is merely the interpretation of the west that the Quran as scripture is the source of violence and terrorism. Chuck counterbalances that neither Islam provides any provision of violence nor the Muslims can put themselves into the shoes of the terrorists.

Since here Chuck had developed a strong sense of his resistance identity. In terms of Baudrillard, we see that Chuck was not merely in the quagmire of adversity and suspension but evolves more strong consciousness towards his identity. Chuck struggles to come out of the American socially abolished and inhumane conditions. He challenges the unjust and stereotypical representation of the Muslims.

\section{- $\quad$ Social Scrutinization of the Muslims}

Laws of the land on citizenship grounds are equal to everyone irrespective of their religion or any other social identity. The rule of law is considered an essential milestone in national rationalism and democratization. America even in the post $9 / 11$ era has been claiming herself as a socially democratic state. But Chuck denies the national claims of America. As contrary to the American claims of democratic state, Chuck was put into prison on account of his suspected Arab identity. In prison, he was humiliated. He was not provided even the fundamental rights which the US constitution had provided to the murderers. "At that moment, however, I realized I couldn't take a walk in the park, much less walk into a prison" (Naqvi, 2010, p.106).

Chuck was shocked that how AC was dismissed from his job for fifteen years on account of the following false charges of terrorism.

- $\quad$ The possession of Arabic literature from AC turned for him as a manual of bomb-making.

- The possession of Muqaddimah Ibn e Khaldun proved as an Anarchist book.

Consequently, AC was framed by the US authorities falsely with four and a half grams of cocaine on him which was equal to the charges of second-degree murder. But later on, AC was proved innocent. It raises questions on the social scrutinization of the Muslims by US authorities.

\section{- $\quad$ Chuck's Reactive Muslim Consciousness as a Counter Strategy}

Once Chuck is encountered with an American girl who questions the meaning of his name. She taunts him on account of his absurd name i.e. Chuck. He says that it is an American name.

'Chuck,' she chuckled. 'What kind a name is Chuck?'

'Well ... I suppose it's American.'

'Are you American?'

'Um, no ... I'm Pakistani.'

'Why'd you have an American name when you're Pakistani?'(Naqvi, 2010, p.201-202)

We see that Chuck was bound to develop ultimately the reactive identity. He was mocked even on his American name which has no meaning. The American girl considers that a Pakistani had no right to have an American name. In such an anarchic and divided society, how can America claim the provision of social justice to all citizens equally? Chuck who initially took pride in his hybridized American and Pakistani identity later on started to discord from it. His act of discarding from his hybrid identity is solid evidence of his will to be defined by his original Muslim identity.

\section{- $\quad$ Redefining the Construct of Fundamentalism}

Michael Leonard a co-worker of Chuck used to speak the dominant American ideology that "Everybody thinks all Muslims are fundamentalists" (Naqvi, 2010, p. 206). Naqvi contrary to American constructed discourse of terrorism provides a sound reason where Americans had failed to differentiate between the perpetrators and the innocent victims of the incident of $9 / 11$. America on account of the religious identity never acknowledged the Muslims as victims who were working in the world trade center at the time of the attack. America partially represented the Americans who died in the bombing as innocent victims, while all other people except American identity were erased. Naqvi questions that were there not any Muslims in the world trade center when it fell. If the Muslims 
can be among the dead ones of the world trade center, how can the Muslims living in America at that time be terrorists and enemies of America? Naqvi deconstructs the American stance and demand the American intelligentsia to feel the sufferings of the Muslims who died in bombing equally with the Americans. Chuck provides that Mr. Shah was attending a conference at the World Trade Centre when tragedy struck... The story was simple, black-and-white: the man was a Muslim, not a terrorist (Naqvi, 2010, p.206)

It provides the readers with a realistic understanding that America in its response to the incident of 9/11 underwent her deeply engrossed national and political ontological understanding of Orientalism. It proved shocking and unbelievable for the people having different ideological identification. For this reason, America failed to be a state suitable for people contrary to the American national label of identity. The American post 9/11 response pragmatically distorted the identity of Muslims politically by charging them as potential terrorists. It proved more a practical manifestation of the pre-existing orientalist model of identification. Chuck disillusioned of these misrepresentations stands for the revival of his identity and develops a sense of collective consciousness of the Muslim identity as a cyclic process of re-writing his identity and self.

\section{- $\quad$ Deconstructing American Political Solipsism}

After the incident of 9/11 Americans asked a question to the whole world as a targeted audience as "Why do they (Muslims) hate us?" Naqvi deconstructs American political solipsism by suggesting that as Chuck, AC, and Muhammad shah were taken as traitors and humiliated, they naturally started defending their religious identity. A close analysis of the novel reveals that Naqvi suggests to America that love begets love and hate begets hate. America did not treat them as individuals but as representative of their religious identity so they start developing a sense of collective identity. In a nutshell, we may lead to the conclusion that America put all the Muslims in the following algebraic equation.

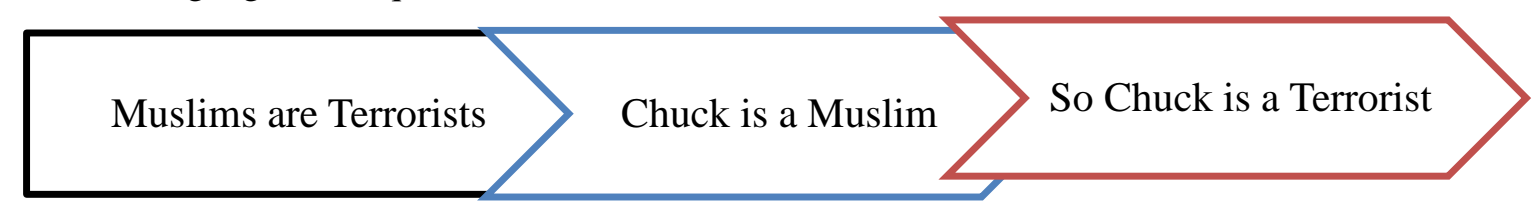

Fig.2

(Americans Hypothetical equation of Muslims and Terrorism)

This is how America was engulfed in indigenous religious extremism and intolerance. We can establish that America took the incident of $9 / 11$ as a new holocaust for them. In misrepresentation of the Muslims as terrorists, America left no tool of discourse unused.

\section{Conclusion}

Relying on Almond (2007) stance in The New Orientalists: Postmodern Representations of Islam from Foucault to Baudrillard and in the light of analyzed data of the novel Home Boy, we can establish that before the incident of 9/11 the American society in religious and political terms was hostile to the Muslims on account of its orientalist binaries. The identity of the Muslims was constructed as berated and negative. The Muslims in America even before the incident of 9/11 was taken as an invisible enemy of America. But after the incident of 9/11, we see that the Western media consciously developed a discourse of terrorism against the Muslims to justify its national and political stigmas. Thus the situation of social exclusion aggravated against the Muslims. The Muslims had to face social discrimination and scrutinization against the name of war against terror. The phenomenon of multiculturalism made it complex for America to differentiate between the identities of the innocent victims of the incident of $9 / 11$ and the perpetrators of this tragedy. The post $9 / 11$ world divided into "US vs. Them" model of social discrimination and raised the situation of collective consciousness. In response to this raised consciousness, the Muslims felt it necessary to write back as a strategy to redefine their distorted identity.

The Western constructed discourse of terrorism is more based on prejudice than on reality. The discursive practices of western discourse enabled Muslims to develop counter-narrative to establish their self and identity against misrepresents of their identity. On account of their position as "Other", the Muslim characters spoke for themselves by engaging in rational to redefine what is meant to be a practicing Muslim. Most importantly it is established that the impression of Muslim- 
hood as a latent seed in every person of Muslim origin in the post 9/11 context is directly linked with the negative outlook of America towards the Muslims.

Chuck is a moderate Muslim but later on, he reverts to his original identity in response to his humiliation in America. Chuck is not a fundamentalist but consciously he becomes fundamental for re-defining his Muslim identity. Furthermore, it emerged from the analysis that individuals of fractured identity are more able to re-write their identity and self against the dominant modes of representation. Naqvi equates that until America continue practicing on orientalist modes, the counter-narrative as a strategy of resistance would continue. Naqvi suggests that American discourse against terrorism is constructed one and the collective consciousness of the Muslims for their identity is natural.

\section{References}

Almond, I. (2007). The new orientalists: Postmodern representations of Islam from Foucault to Baudrillard. Bloomsbury Publishing.

Buchowski, M. (2006). Social thought \& commentary: the specter of Orientalism in Europe: from exotic other to stigmatized brother. Anthropological Quarterly, 79(3), 463-482.

Burke, P. J., \& Stets, J. E. (2009). Identity theory. Oxford University Press.

Castells, M. (2011). The power of identity (Vol. 14). John Wiley \& Sons.

Erikson, E. H. (1968). Identity: Youth and crisis (No. 7). WW Norton \& Company.

Giroux, H. A. (2009). Paulo Freire and the politics of post colonialism. In breaching the colonial contract (pp. 79-89). Springer, Dordrecht.

Haugaard, M., \& Lentner, H. H. (Eds.). (2006). Hegemony and power: consensus and coercion in contemporary politics. Lexington Books.

Hoffman, B. (2006). Inside terrorism. Columbia university press.

Lewis, M. (1990). Self-knowledge and social development in early life.in Pervin.L.A Handbook of Social Psychology (Guilford: Newyork, 1990)

Mills, S. (1993). Discourses of difference: an analysis of women's travel writing and colonialism. Psychology Press.

Morris, R. (Ed.). (2010). Can the subaltern speak? Reflections on the history of an idea. Columbia University Press.

Said, E. (2002). Islam and the West are inadequate banners. Fellowship, 68(1-2), 5.

Woodward, K. (2004). Questions of identity. In questioning identity (pp. 13-50). Routledge.

Naqvi, H. M. (2010). Home boy (Vol. 47). IL Saggiatore. 